\title{
Development of Video Media to Increase Dribbling Learning Result in A Sport Games
}

\author{
Nawawi ${ }^{1}$, I Nyoman Sudana Degeng ${ }^{2}$, Abd. Cholid ${ }^{3}$ \\ 1,3Teknologi Pendidikan, Universitas PGRI Adi Buana Surabaya \\ ${ }^{2}$ Teknologi Pembelajaran, Universitas Negeri Malang
}

\section{Edcomtech}

Jurnal Kajian

Teknologi Pendidikan

Volume 4, No 2, Oktober 2019

83-88

Submitted 02-01-2019

Accepted 28-08-2019

Corresponding Author

Nawawi,

nawawihilwa996@gmail.com

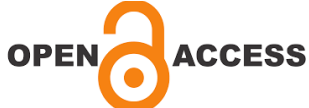

\begin{abstract}
Physical sports and healthy Education is one of the subjects that students like especially football game. Dribbling video media on football games is one of the solutions that are expected to motivate students to learn independently, creatively, effectively and efficiently. Therefore, it is necessary to develop the learning material of football game technique. technique to attract interest and reduce the saturation of learning in the students of class $X$ Computer and Network Engineering (TKJ) which is designed interesting and specially designed in the form of CD media and dribbling technique skill manual on football game. Model development of dribbling video media learning on football game used is Dick and Carey model. Media video dribbling on the game of football and tested through 2 stages, namely (1) Expert test that is the review of the content experts / learning materials; learning media experts; and design experts, (2) Field test is individual group testing; small group trial; and large group trials. Based on the responses given by experted on dribbling video media on football games is like to use. Based on the responses given by the students of class $X$ TKJ semester 2 as respondents to dribbling video media product on football game is feasible to be used by students of class X TKJ semester 2.
\end{abstract}

Keywords: Video, Media, Dribbling 


\section{INTRODUCTION}

Physical education and exercise are parts integral to overall education, aiming to develop aspects of physical fitness, movement skills, social skills, stability emotional, moral actions, aspects of a healthy lifestyle, and introduction of clean environment by Achmad Sofyan (2013: 441). Hanafi Hasibuan (2017: 130-131) said there for educational purposes physical sports and health can really achieved well, it is necessary a more in-depth review of the concept of sports physical education and health. For this reason, quality sports physical Education and health both in terms of material and delivery, materials teaching, educators, facilities and participants students need to be studied more deeply. The results of field observation (class) on the teaching and learning process (PBM) in general and in SMK class $X$ in particular shows the activity of students in the teaching-learning process is low and passive that tends only as the recipient only. Students do not seem eager for many sleepy, especially in the hours after the break starting at 14:00 pm and less attention to the material presented by the teacher. Students are less interested during the learning process, students are less daring to express their opinions when asked by the teacher so that the process of teaching and learning activities is dominated by taking notes on the blackboard and lecture. Student learning interest is important to be improved because it simplifies the learning process as well as to achieve higher achievement than ever. Interest is a basic motivational tool because the learning process will run smoothly if accompanied by interest. Concerning this interest, among others, can be generated in the following ways: using a variety of teaching methods, generating a need, giving an opportunity to get better results (Sardiman, 2006: 95). Dribbling video media on football games is one of the solutions that are expected to motivate students to learn independently, creatively, effectively and efficiently. In addition to the media video dribbling on this football game, is expected to reduce the saturation of students because during this learning process conducted by most schools is the method of face to face (lecture). According to Karnoto (2019: 142), basic abilities playing football must be mastered. The basics of playing football include: dribbling, passing, shooting, heading headings, juggling, stopping the ball and throw-in. Therefore, to respond to the problems contained in the background above, the development develop dribbling video media on a game of football that has never existed in the students of class $X$ Computer and Network Engineering (TKJ) on the Physical Sport and healty education subject by using media video dribbling on the game of football in the hope to attract the student learning so that the results of learning better again.

The purpose of this development is to create and develop dribbling video media on football games on Physical sport and healthy Education subject class $X$ TKJ and made a video dribbling on football game.

Another purpose is to produce a computerbased (video) learning media that is validated and effective subjects used in school according to Suci Cahyati, Wawan S. Suherman (2014: 71).

Azhar Arsyad (2011: 49) states that the video is an image in the frame, where frame by frame is projected through the lens of the projector mechanically so that the screen looks like image.

According to I Wayan Agus Budiarsa, I. P. Panca Adi, and M. A.Wijaya (2018: 2) One of the main function of learning media is as participating teaching aids motivate students in the process learning.

\section{METHOD}

Research and Development is a research method used to produce products certain, and test the effectiveness of the product (Sugiyono, 2010: 407). According to Seel \& Richey in Punaji (2013: 223), defines research development as follows: "Developmental research as opposed to simple instructional development, has been defined as the systematic study of designing, developing and evaluating instructional programs, processes and products that must meet the criteria of internal consistency and effectiveness".

The learning model of dribbling video media learning on football game used is the model most used by learning and training designer that 
is Dick and Carey model (2001: 2-3) written in book The Systematic Design of Instruction 5th edition there are 10 stages of process done from the beginning of development to the product as a result of development, which are: Analyze the need to identify the teaching objectives, analyze the instructional, analyze the learners and the context / characteristics, write the objectives of specific performance / instruction, develop the benchmark reference assessment instrument, develop the learning strategy Develop and select learning materials, design and carry out formative evaluations, revise learning and design and implement summative evaluations.

Procedures taken in the development of this product are:

Phase I identifies and defines the overall general objectives of learning to be achieved in learning, phase II of the process of analyzing learning by taking into account the basic competencies of physical and physical education subjects that are in Class $\mathrm{X}$ Computer and Networking techniques, stage III identification of student's initial characteristics and knowledge, the fourth stage of determining the specific objectives of learning developed from the learning analysis phase, stage $V$ distributing questionnaires / questionnaires of basic competence students, stage VI develop learning strategies, stage VII selection of learning materials in the form of modules and literature and development of related learning materials, and adjust situations that exist at the location where this development is implemented, stage VIII improve prototype product development obtained from the Experts and the subject of trials and then developed so that the video media dribbling on the game of football in accordance hoped, stage IX is not done because the purpose of this product development is limited to a media video dribbling on the game of football.

Stage $X$ is not done because the purpose of this product development is limited to a video media dribbling on the game of football.

The testing stages for the development of dribbling video media on the game of football is designed as follows: Subject where the dribbling video media product on the game of football developed and tested divided into:
Expert content / learning materials, learning media, learning design (Martin Artiyono Pratama, Mohamad Amin, Endang Suarsini 2016). Like proportional group, Small groups. Large groups. Type data, appropriate content of learning materials, precision of media design, precision and beauty of design, dribbling video media hope on football games, dribbling video media effectiveness on football games. The implementation of this study students not only watched learning videos but also doing learning movements or activities about techniques basic on football as written by Joan Rhobi Andrianto (2014: 90). Instruments to obtain expected data for product development can be said ideal, used in the form of a questionnaire instrument / questionnaire and documentation. Analysis data after the data collected, the next step is to perform data analysis. This research development uses 2 data analysis techniques, which is descriptive quantitative analysis technique and qualitative descriptive analysis as written by Wedastama, Pudjawan \& Tegeh (2013: 7). The quantitative descriptive analysis technique is used to process the data in the form of numbers and obtained from questionnaire in descriptive form. While qualitative descriptive analysis is more descriptive not numeric. As for the formula used to calculate the percentage of each subject is:

$N P=(\Sigma N R) /(\Sigma N I) \times 100 \%$.

Information:

$$
\begin{aligned}
& \mathrm{NP}= \begin{array}{l}
\text { Percentage Value of } \\
\text { Questionnaire } / \text { Questionnaire }
\end{array} \\
& \Sigma \mathrm{NR}=\begin{array}{l}
\text { Total number of respondents } \\
\text { answers }
\end{array} \\
& \Sigma \mathrm{NI}=\text { Total number of ideal values }
\end{aligned}
$$

Next to calculate the percentage of the

$$
P=F / n
$$

Information:

$$
\begin{aligned}
& \mathrm{P}=\text { Value Percentage of overall subject } \\
& \mathrm{F}=\begin{array}{l}
\text { Total percentage of the entire } \\
\text { subject }
\end{array} \\
& \mathrm{N}=\text { Many subjects }
\end{aligned}
$$


Where to provide meaning and decisionmaking level of eligibility is used conversion rate of achievement as follows.

Whole subject is to use the following formula.

Table 1. Eligibility Criteria

\begin{tabular}{|c|c|l|l|}
\hline Category & Percentage & Equivalent & Qualification \\
\hline A & $80-100$ & Valid & Valid \\
\hline B & $60-79$ & Quite & Enough \\
\hline C & $50-59$ & Less Valid & Less Worthy \\
\hline D & $0-49$ & Invalid & Invalid \\
\hline
\end{tabular}

Source: Arikunto (2016) Prosedur Penelitian Suatu Pendekatan Praktik

\section{RESULT AND DISCUSSION}

The result data obtained from expert content / learning material that viewed from the side of effectiveness, attractiveness, and efficiency of dribbling video media on football game is $85.57 \%$. It is then converted into a table of eligibility criteria. Then the dribbling video media on the game of football is classified as valid qualification so it can be said feasible.

The data obtained from the results of learning media experts viewed from the side of effectiveness, attractiveness, and efficiency of learning media is $94.44 \%$. Then converted into the table of eligibility level eligibility. Then the dribbling video media on the game of football is classified as valid qualification so it can be said feasible.

Data obtained from the results of learning design expert who viewed from the side of effectiveness, attractiveness, and efficiency of dribbling video media on the game of football is $84.72 \%$. It is then converted into a table of eligibility criteria. Then the dribbling video media on the game of football is classified as valid qualification so it can be said feasible.

The trial data obtained from a group of 3 students is required to test small errors on dribbling video media on football games is $81.37 \%$. It is then converted into a table of eligibility criteria. Then, the dribbling video media on the game of football is classified as valid qualification so it can be said feasible.

Trial data obtained from the results of the overall assessment of respondents in a small group of 10 student's field trials of dribbling video media on football games is for the general display component, all respondents support the percentage of components of $76.00 \%$. The visual display component or image on each page, the percentage of components is $80.00 \%$. The text display component on each page, the percentage of the component is $72.00 \%$. Components of the content framework presented, the percentage of components of $88.00 \%$. Components of material clarity, component percentage of $82.00 \%$. Audio sound clarity component, component percentage of $86.00 \%$. Component of exercise feedback existence, component percentage of $82.00 \%$. The last component of the response/assessment is the structure of the presentation of the material, the percentage of components of $82.00 \%$. In general it can be concluded that the average percentage of respondent expression in small group testing of dribbling video media on soccer game on subjects of physical and sports physical education $81.00 \%$. This means that the dribbling video media development product on the game of football is in a valid equivalent qualification worthy to be used as a dribbling video medium on the game of football in learning.

Valid data obtained from the results of the overall assessment of respondents' answers in a large group of 32 students and 2 productive teacher colleagues in field trials of dribbling video media on football games. For a given component the overall assessment/response is the same as for small groups in general it can be concluded that the mean percentage of respondent expression in large group trials of dribbling video media on soccer games in the subject of physical and health education of $7.750 \%$. Means dribbling video media development products on football games are in qualification quite valid equivalent enough decent enough to be used as a medium of dribbling video on the game of football in learning.

\section{SUMMARY \\ Conclusion}

Learning design that uses dribbling video media on football games on Physical and Health Physical Education subjects that 
follow Dick and Carey learning development model on the subject of Physical Education of Sport and Health is packed into CD/DVD and handbook and used in class X (ten) Computer and Network Engineering (TKJ). From the results of the development that has been tested, has been successfully tested and it has already shown that video media able to improve the teacher strategy in conveying the message content contained in the learning, and able to meet the need for saturation of students/learners.

Objectively, it must be admitted that the developer, dribbling video media on this football game there are deficiencies/ weaknesses of this developed product. Here are the disadvantages of dribbling video media on football games, such as:

1. With the limited time of trial testers, then not all learning materials in this development product tested try through actual learning activities.

2. With the complexity in making a product that is very time-consuming in the making so that the validation time and test testers after the prototype has been developed using the expert with minimum requirements, namely the graduate (S2) ideally is to use the experts who graduated from doctoral program (S3).

3. Experts appointed as validators to validate the product development is still using experts from the local/research location where the location / location of the study is still the place/location of the work unit of the developer, so that the element of subjectivity is still strong attached even in this case the developer keep trying as professional as possible with no element of influence in the filling of questionnaires/questionnaires given developers to experts.

\section{Suggestion}

To be more optimal in using dribbled video media products on football games developed by developers. It is advisable will be easier to use if the user before understanding the basic techniques of football games. This product also need to be tested as a whole of the content of learning material that exist in media, and need to be tested to the experts is indeed a professional in their field in accordance with the required and in line with the knowledge possessed by experts with media that is validated for dissemination of wider. Suggested in order it is tested to several equivalent schools with various characteristics of learners, and well prepared before developing a medium of learning both in terms of layout; story board; time; sample; the experts; and product manufacturer teams for the purposes of further development this media.

\section{REFFERENCES}

A. M., Sardiman. (2006). Interaksi dan Motivasi Belajar Mengajar. Jakarta: PT. Raja Grafindo Persada.

Andrianto, Joan Rhobi. (2014). Pengembangan Model Latihan Teknik Dasar Ball Feeling Sepakbola Menggunakan Media Pembelajaran Audio Visual pada Siswa Usia 11 Tahun Sekolah Sepak Bola Sanggar Kegiatan Belajar (SSB SKB) Gudo Kabupaten Jombang. Bravo's (Jurnal Program Studi Pendidikan Jasmani dan Kesehatan) STKIP PGRI Jombang. Vol. 2, No. 3.

Arikunto, Suharsimi. (2016). Prosedur Penelitian: Suatu Pendekatan Praktik. Jakarta: Rineka Cipta.

Arsyad, Azhar. (2013). Media Pembelajaran. Jakarta: PT. Rajagrafindo Persada.

Budiarsa. I Wayan Agus, Adi. I. P. Panca, Wijaya. M. A. (2018). Pengembangan Media Pembelajaran PJOK Berbasis Kartu Gerak pada Materi Aktivitas Pengembangan untuk siswa kelas VII. E_ Journal Pendidikan Jasmani, Kesehatan dan Rekreasi. Fakultas Olahraga dan Kesehatan, Undiksha, Vol. 9, No. 1.

Cahyati. Suci, Suherman. Wawan S. (2014). Pengembangan Media Pembelajaran Pendidikan Jasmani Olahraga dan Kesehatan Berbasis Komputer untuk SMA. Jurnal Keolahragaan Program Studi Keolahragaan, Program Pascasarjana, Universitas Negeri Yogyakarta. Volume 2 - Nomor 1.

Cholid A, Abd. (2013). Petunjuk Permainan sepakbola Usia Dini Menuju Prestasi. 
Universitas PGRI Adi Buana Surabaya.

Dick, Walter, Lou Carey, and James O Carey. 2005. The Syistematic design of Instruction (Eds. 6). Boston. Pearson.

Hasibuan, Hanafi. (2017). Jurnal Teknologi Informasi dan Komunikasi dalam Pendidikan, Program studi Teknologi Pendidikan, Universitas Negeri Medan. Vol. 4, No. 2.

Karnoto. (2019). Penerapan Media Video untuk Meningkatkan Pembelajaran Dribbling dalam Permainan Sepak Bola pada Mata Pelajaran Pendidikan Jasmani Olahraga dan Kesehatan. Jurnal Ilmiah Pendidikan Humanoria. Volume V, Nomor 1.

M.A. Pratama, M. Amin, E. Suarsini. (2016). Jurnal Pendidikan: Teori, Penelitian, dan Pengembangan, Pascarsarjana, Universitas Negeri Malang. Vol. 1, No. 10.
Punaji, Setyosari. (2013). Metode Penelitian Pendidikan dan Pengembangan. Jakarta: Kencana Prenada Media Group

Sofyan, Achmad. (2013). Penerapan Teknologi Pembelajaran Audio Visual Terhadap Hasil Belajar Dribbling Sepak Bola di SMA Negeri 1 Bondowoso. Jurnal Pendidikan Olahraga dan Kesehatan, Universitas Negeri Surabaya. Volume 01 Nomor 02.

Sugiyono (2010). Metode Penelitian Pendidikan, Bandung: Alfabeta.

Wedastama. Putu, Pudjawan. Ketut, Tegeh, I Made. (2013). Pengembangan Media Video dribbling pada pertandingan sepak bola Berbasis Web pada Mata Pelajaran KKPI Kelas X Semester Ganjil di SMK Negeri 2 Singaraja Tahun Pelajaran 2012/2013. eJournal Edutech (JJTP). Vol 1 No. 2. 